Published in final edited form as:

Cancer Epidemiol. 2018 August ; 55: 170-175. doi:10.1016/j.canep.2018.06.009.

\title{
Domperidone use and risk of primary liver cancer in the Clinical Practice Research Datalink
}

\author{
Jake E. Thistle ${ }^{1}$, Jessica L. Petrick ${ }^{1}$, Baiyu Yang ${ }^{1,2}$, Marie C. Bradley ${ }^{3}$, Barry I. Graubard ${ }^{1}$, \\ Katherine A. McGlynn ${ }^{1}$ \\ ${ }^{1}$ Division of Cancer Epidemiology and Genetics, National Cancer Institute, Bethesda, MD \\ ${ }^{2}$ Stanford Cancer Institute, Stanford University, Palo Alto, CA \\ ${ }^{3}$ Center for Drug Evaluation and Research, US Food and Drug Administration, Silver Spring, MD
}

\begin{abstract}
Background.-Pronounced sex-disparity in liver cancer suggests a role for hormones, one of which could be prolactin. Stimulation of prolactin production in mice via domperidone has been reported to decrease hepatocarcinogenesis, thus may have chemopreventive potential. To study the effect of domperidone in humans, a large medical records study was conducted.
\end{abstract}

Methods.-Based in the Clinical Practice Research Datalink, 1,921 liver cancer cases and 7,681 controls were identified. Conditional logistic regression was employed to estimate odds ratios (OR) and 95\% confidence intervals (CI). Domperidone use was analyzed overall, and by number of prescriptions and cumulative dose.

Results.-Comparing ever- versus never-use, there was no association between domperidone and liver cancer among men (OR=1.06, 95\% CI: $0.76-1.48)$ or women (OR=1.21, 95\% CI: 0.82-1.76). Among men, there was no association with dose or number of prescriptions, while among women

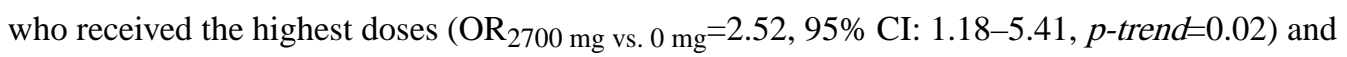
greatest number of prescriptions $\left(\mathrm{OR}_{\geq 11 \mathrm{Rx} \text { vs. } 0 \mathrm{Rx}}=3.17,95 \% \mathrm{CI}\right.$ : $1.07-9.40$, $p$-trend $\left.=0.02\right)$ there was a significantly increased risk, although there was no evidence of heterogeneity in the results by gender.

Corresponding Author: Katherine A. McGlynn, Division of Cancer Epidemiology and Genetics, National Cancer Institute, Rockville, MD, 9609 Medical Center Drive, Bethesda, MD, 20850. mcglynnk@ mail.nih.gov. Phone: 240-276-7297, Fax: 240-276-7838.

Authorship contributions:

Conception and design: Baiyu Yang, Barry I. Graubard, Katherine A. McGlynn

Financial and administrative support: Katherine A. McGlynn

Collection and assembly of data: Jake E. Thistle, Baiyu Yang, Jessica L. Petrick, Katherine A. McGlynn

Data analysis: Jake E. Thistle, Baiyu Yang, Katherine A. McGlynn

Data interpretation: All authors

Manuscript writing: Jake E. Thistle, Katherine A. McGlynn

Review and approval of manuscript: All authors

Conflict of Interest: The authors declare no potential conflicts of interest.

Ethical Approval: All procedures performed in studies involving human participants were in accordance with the ethical standards of the institutional and/or national research committee and with the 1964 Helsinki declaration and its later amendments or comparable ethical standards. The research was approved by the Institutional Review Board of the National Cancer Institute. This study does not contain any animal experiments performed by any of the authors.

Submission declaration: This manuscript has not been published and is not under consideration for publication elsewhere. 
Conclusion.-Domperidone use was not associated with decreased liver cancer risk among all study participants. Among women, an increased risk at highest levels of exposure warrants further study.

\section{Keywords}

Domperidone; liver cancer; prolactin; hormones; CPRD; sex-disparity; sex-discrepancy

\section{Introduction}

Liver cancer is the sixth most commonly occurring cancer in the world and the second leading cause of cancer mortality [1]. In almost all areas of the world, the incidence of liver cancer is three- to four-fold higher among men than women [2]. Men also have higher recurrence rates and poorer survival after diagnosis of liver cancer than do women [3, 4]. Reasons for this gender disparity are not clear. While some major risk factors, such as infection with hepatitis B virus (HBV) or hepatitis C virus (HCV), excessive alcohol consumption, and cigarette smoking, are more common among men, these factors do not fully account for the gender differences in liver cancer incidence and survival [2].

A role for endogenous hormones in the gender discrepancy in liver cancer risk has been hypothesized, with most speculation focusing on testosterone or estradiol [5-8]. However, the role of estrogenic exposures remains unclear, as studies have reported mixed results for parity [9-15], oral contraceptive use [16], and menopausal hormone therapy [15, 17, 18], although two studies have shown an increased liver cancer risk associated with bilateral oophorectomy $[15,18]$. Other hormones could also play a role in liver cancer development. Prolactin is an estrogen-responsive hormone secreted by the pituitary gland that is expressed at higher levels among women than among men [19]. While its role in reproduction, including lactation, menstruation, and sexual behavior, is well characterized, prolactin also plays extensive roles in numerous other processes including immune response regulation [20]. Prolactin exhibits immunostimulatory properties and protects against inflammation under severe stress, such as trauma [21].

Whether the higher levels of prolactin found in women could underlie the gender difference in liver cancer risk is not known. Prolactin secretion, however, can be increased by domperidone, a dopamine antagonist that is commonly prescribed for the amelioration of nausea and vomiting [22, 23]. Experiments in mice, one of which employed domperidone, have reported that stimulation of prolactin production decreased liver tumorigenesis [24, 25]. As liver cancer rates are rising and survival rates remain poor, identification of possible chemopreventive agents could provide an effective intervention in high-risk populations. Thus, to examine the hypothesis that domperidone use, and by extension higher prolactin levels, is associated with decreased liver cancer risk in humans, a large study in a medical records database was undertaken. 


\section{Materials and Methods}

\section{Study Population}

A nested case-control study was conducted within the Clinical Practice Research Datalink CPRD, a United Kingdom (UK) database of anonymized, population-based electronic medical records. In the UK, universal health coverage is provided by the National Health Service, and the age and gender distributions in the CPRD are representative of the general UK population $[26,27]$. The CPRD contains medical data on approximately $8.5 \%$ of the population. Data, including demographic information, medical diagnoses, hospital referrals, and prescriptions, are collected on a monthly basis from general practitioners [28]. Clinical information is recorded using Read codes and all prescribing information for medications is captured in an anonymous format. Validity studies have shown the CPRD to be reasonably complete and accurate regarding clinical illness diagnosis and prescription medication information [28]. Supporting medical documents routinely show that diagnoses in the CPRD are present in more than $90 \%$ of clinical records [29] and approximately $97 \%$ of primary cancers recorded in CPRD are confirmed as incident by other sources (e.g. cancer registry) [30]. The study was approved by the National Institutes of Health (NIH) Human Research Protection Program and the Independent Scientific Advisory Committee of the CPRD.

Liver cancer cases and controls were selected from persons between the ages of 10 and 90 years who were enrolled in the CPRD between 1987 and 2016. Cases met the following criteria: 1) had a first-time diagnosis of primary liver cancer; 2) had no prior diagnosis of cancers most likely to metastasize to the liver (lung, stomach, breast, colon, or pancreatic cancer); 3) had no code of liver cancer metastases; and 4) had at least three years of history in the CPRD prior to their diagnosis date. A total of 1,938 cases were identified. For each case, controls were selected from individuals who were in the CPRD on the case's diagnosis date and had no liver cancer diagnosis prior to that date. Controls were matched to cases at a four-to-one ratio on age (same year of birth), sex, general practice, and date of enrollment in CPRD. The great majority of cases $(n=1,918 ; 99 \%)$ were successfully matched to 4 controls. However, 3 cases were only matched to 3 controls, and no controls were identified for 17 cases. Cases for whom no control could be identified were excluded from the study. Thus, the final study population included 1,921 liver cancer cases and 7,681 controls.

All domperidone prescriptions (i.e., domperidone, paracetamol combined with domperidone) were identified based on product codes recorded in the medical record. Prescriptions written from the time of CPRD entry to 1 year before case's diagnosis were included. Prescriptions within one year of diagnosis were excluded to eliminate possible bias associated with changes in health associated with pre-symptomatic liver cancer. To assess whether a dose-dependent relationship existed, domperidone use was categorized by the cumulative dose (summation of doses in each prescription) and the number of prescriptions. Prescriptions were additionally stratified by time since last use (1-<2 years vs $\geq 2$ years). Covariates included body mass index (BMI), diagnoses of alcohol-related disorders, smoking status, HBV or HCV infection, diabetes, statin use, and diagnoses of rare genetic disorders known to be associated with liver cancer (i.e., hemochromatosis, tyrosinemia, Wilson Disease, alpha-1-antitrysin deficiency, porphyrias) based on medcodes or product 
codes preceding the date of liver cancer diagnosis. For covariates that vary with time, such as smoking status and BMI, status was based on the determination in closest proximity to the index date/date of diagnosis.

Conditional logistic regression was used to estimate odds ratios (OR) and 95\% confidence intervals (CI) for the association between domperidone use and development of liver cancer, with adjustment for all covariates. Domperidone use was defined as the receipt of one of more prescriptions for the drug. Missing values for BMI (11.4\% of cases and $8.9 \%$ of controls) and smoking status ( $2.4 \%$ of cases and $4.6 \%$ of controls) were derived, as a single imputation, using the PROC MI procedure (SAS Institute Inc., Cary, NC). Tests for trend were constructed using the median value of each categorization of the cumulative dose and number of prescriptions. All analyses were stratified by sex to evaluate any sex-specific effects of domperidone use. Effect measure modification by sex was evaluated by testing for deviation from a multiplicative interaction model, using the likelihood ratio test to compare the fit of models with and without an interaction term. Additionally, as domperidone could theorectically have been prescribed to premenopausal women for lactation purposes, a sensitivity analysis that stratifying by age at first use (before/after age 50 years) was conducted. All tests were 2 -sided. Statistical significance was identified by $p$-values less than 0.05. All analyses were performed in SAS 9.3 (SAS Institute Inc., Cary, NC).

\section{Results}

Overall, the median length of enrollment in CPRD was 10.3 years (range 6.5 to 14.6 years), with the median being slightly longer among men (10.4 years) than among women (9.9 years). Characteristics of the cases and controls are shown in Table 1. Among both men and women, cases were more likely than controls to be current smokers, have chronic HBV and/or HCV infection, have diabetes, have an alcohol related-disorder and have a rare genetic disorder. Male cases, compared to female cases, were more likely to be obese, to be ever smokers (current and former), and to have chronic HBV and/or HCV infection, diabetes, alcohol-related disorders and rare genetic disorders.

The associations between domperidone use and liver cancer are shown in Table 2. Among the cases, $4.8 \%$ had received prescriptions for domperidone, with an average cumulative dose of $2315 \mathrm{mg}$. Among the controls, 3.9\% had received prescriptions for domperidone, with an average cumulative dose of $4176 \mathrm{mg}$. Comparing ever versus never use, there was no association between domperidone and liver cancer risk among men $(\mathrm{OR}=1.06,95 \% \mathrm{CI}$ : $0.76,1.48)$ or among women $(\mathrm{OR}=1.21,95 \% \mathrm{CI}: 0.82,1.76)$. In addition, there was no meaningful difference in liver cancer risk when stratified by time since last use.

The analyses of number of prescriptions and cumulative dose, however, resulted in somewhat discrepant findings among men and women. Among men, there were no significant association between risk and either number of prescriptions ( $p$-trend $=0.62)$ or cumulative dose ( $p$-trend $=0.57$ ). Among women however, there was an elevated risk of liver cancer with increasing cumulative dose $(p$-trend $=0.02)$ and number of prescriptions ( $p$-trend $=0.02$ ). In particular, higher risk was found among women who received the highest cumulative dose $\left(\mathrm{OR}_{2700} \mathrm{mg}\right.$ vs. $0 \mathrm{mg}=2.52,95 \%$ CI: $\left.1.18,5.41\right)$ and the greatest 
number of prescriptions ( $\left.\mathrm{OR}_{\geq 11 \mathrm{Rx} \text { vs. } 0 \mathrm{Rx}}=3.17,95 \% \mathrm{CI}: 1.07,9.40\right)$. Stratification by age at first use among women ( $<50$ yrs. vs $\geq 50$ yrs.), however, did not identify any differences in results (data not shown). To determine whether the results between men and women were meaningful, an interaction analysis was conducted which found little evidence of heterogeneity. In examining cumulative dose, the $p$-value for interaction was $p=0.19$, while the $p$-value for interaction of the number of prescriptions was $p=0.21$.

\section{Discussion}

This study comprehensively evaluated the association between domperidone use and liver cancer, utilizing medical data recorded by general practitioners. Overall, no association between use of domperidone and liver cancer risk was identified. There was, however, a significantly increased risk among women who received the greatest number of prescriptions. There was no evidence of heterogeneity in the gender specific results, however, suggesting that the results among women will need confirmation in future studies. These results suggest that prescribing domperidone to increase prolactin levels is unlikely to be an effective way to prevent liver cancer.

To date, no other population-based studies have examined the role of domperidone and liver cancer risk. Two laboratory studies conducted among mice, however, reported that stimulation of prolactin production decreased risk of liver cancer among males [31]. One of the two studies administered domperidone, thus the results of that experiment are more closely related to the results reported in the current manuscript. Reasons for the dissimilarity in results are unclear, but could potentially be due to domperidone being administered to mice with pre-neoplastic hepatic alterations, suggesting that the effect of domperidone was related to progression of disease rather than initiation [31]. In addition, only male mice were included in the laboratory experiment [31], thus it is unclear what effect domperidone would have had on female mice. Alternatively, the effect of prolactin on liver cancer may vary across species as prolactin has been suggested to act as a tumor promoter in rats [24, 32].

In humans, domperidone has anti-dopaminergic, prolactin stimulating effects in both men and women [33], with women reported to have stronger domperidone-dependent prolactin stimulation than men [34]. A prior population-based study reported increased cancer risk among persons with hyperprolactinemia [35]. In specific, there was an increased risk of upper and lower gastrointestinal cancer, with a higher risk among women than men. Other studies have reported higher prolactin levels among persons with several cancer types [3640], including hepatocellular carcinoma, the dominant histological type of liver cancer [4144]. In these cross-sectional studies, serum prolactin levels, or protein expression of prolactin in tissue samples, were significantly higher in hepatocellular carcinoma cases than in controls [41-44]. Additionally, in a study of human liver tissue [45], prolactin receptor expression was increased in fibrosis and cirrhosis in contrast to normal liver tissue. While these data suggest that serum prolactin expression may be increased in liver disease [45, 46], it is unclear that they are relevant to the current findings as the previous studies examined prolactin levels among persons with liver cancer or liver disease, conditions known to be associated with numerous metabolic perturbations.

Cancer Epidemiol. Author manuscript; available in PMC 2020 February 10. 
Domperidone is used to treat a variety of gastrointestinal disorders [47], including nausea and vomiting. As these symptoms may be due to different underlying etiologies, confounding by indication could conceivably be related to the elevated risk of liver cancer among women. Furthermore, domperidone was available over-the-counter for a brief period in the U.K. (sold under the brand name Motilium), and studies have reported other "offlabel" uses, including treatment of gastroesophageal reflux disease or indigestion [48, 49]. However, the most common indication for off-label use among women is stimulation of lactation in the presence of inadequate breast milk production [49]. In the current study, fewer than $20 \%$ of women first took domperidone before 50 years of age, the average age of menopause, suggesting that the use of domperidone to stimulate breast milk production is unlikely to explain the sex-specific effect on liver cancer risk.

It is unclear whether the findings in the current study support sex-specific differences in results, but if so, it is possible that the differences are related to sex-differences in the activity of enzymes involved in the metabolism of domperidone [50,51]. Domperidone is catabolized primarily by cytochrome P450 (CYP) isozyme CYP3A4 [52, 53]. While CYP3A4 is expressed at 2-fold higher levels among women [54], the clinical significance of this, in relation to domperidone use, is unknown. Another possible explanation for the sex difference in the current study is that the male cases were more likely than the female cases to have one or more known risk factors for liver cancer (e.g., obesity, diabetes, chronic $\mathrm{HBV} / \mathrm{HCV}$ infection, alcohol-related disorder, rare genetic disease). It is thus, conceivable, that any small additional risk of liver cancer among males would be harder to detect on a background of higher overall risk.

Major strengths of this study were the use of a validated, population-based, longitudinal database from a representative sample of the UK population, and the relatively large sample size. Additionally, the CPRD has been demonstrated to have completeness of cancer diagnoses and information on prescription medications [28, 29]. As the data are captured prospectively in medical records that are routinely collected, recall and self-report biases are minimal. In addition, as the UK has a universal healthcare system, potential systematic exclusion of specific socioeconomic groups was minimized. Finally, the data analysis accounted for many potential confounding factors, including BMI, diabetes, alcohol-related diagnoses, smoking, and HBV/HCV infection.

In addition to its strengths, the study also had several limitations. It is possible, in theory, that some secondary liver cancers were classified as primary liver cancers, as diagnoses were not confirmed by linkage to a cancer registry. However, to minimize this possibility, persons with a diagnosis of lung, stomach, breast, colon, or pancreatic cancer in the past 5 years were excluded from the study. Chronic HBV and HCV infections are likely to be underascertained in any medical record database, as persons with chronic infections can be asymptomatic and serologic tests are only ordered when there is an indication to do so. The CPRD has not always consistently recorded racial and ethnic information, thus the effects of race/ethnicity on the results could not be examined. The UK population, however, is predominantly white, thus any effect of race/ethnicity is likely to be minimal. Finally, regarding prescriptions, the study did not concurrently examine the use of other medications, could not examine adherence to domperidone prescriptions, and could not include any over- 
the-counter domperidone use during the time period when over-the-counter use was an option.

This is the first study to evaluate domperidone use and liver cancer in humans. The findings do not support the hypothesis that increasing prolactin levels via domperidone is likely to decrease the risk of liver cancer. A suggestion of increased risk among women, however, is a concern that warrants further study.

\title{
Acknowledgements.
}

The authors wish to thank Drs. Michael B. Cook, Shahinaz Gadalla and Julia Gage of DCEG, NCI for participating in covariate creation. The authors wish to thank Emily Carver and David Ruggieri of Information Management Systems, Inc. for assistance with data curation and file preparation.

Grant Support: NIH Intramural Research Program, National Cancer Institute

\author{
Abbreviations: \\ CPRD Clinical Practice Research Datalink \\ HBV hepatitis B virus \\ HCV hepatitis C virus
}

\section{References}

[1]. Valery PC, Laversanne M, Clark PJ, Petrick JL, McGlynn KA, Bray F, Projections of primary liver cancer to 2030 in 30 countries worldwide, Hepatology (2017).

[2]. McGlynn KA, Petrick JL, London WT, Global epidemiology of hepatocellular carcinoma: an emphasis on demographic and regional variability, Clin Liver Dis 19(2) (2015) 223-38. [PubMed: 25921660]

[3]. Fukuda S, Itamoto T, Amano H, Kohashi T, Ohdan H, Tashiro H, Asahara T, Clinicopathologic features of hepatocellular carcinoma patients with compensated cirrhosis surviving more than 10 years after curative hepatectomy, World J Surg 31(2) (2007) 345-52. [PubMed: 17219274]

[4]. Ng IO, Ng M, Fan ST, Better survival in women with resected hepatocellular carcinoma is not related to tumor proliferation or expression of hormone receptors, Am J Gastroenterol 92(8) (1997) 1355-8. [PubMed: 9260806]

[5]. Kuper H, Mantzoros C, Lagiou P, Tzonou A, Tamimi R, Mucci L, Benetou V, Spanos E, Stuver SO, Trichopoulos D, Estrogens, testosterone and sex hormone binding globulin in relation to liver cancer in men, Oncology 60(4) (2001) 355-60. [PubMed: 11408804]

[6]. Yu MW, Chen CJ, Elevated serum testosterone levels and risk of hepatocellular carcinoma, Cancer Res 53(4) (1993) 790-4. [PubMed: 8381328]

[7]. Yuan JM, Ross RK, Stanczyk FZ, Govindarajan S, Gao YT, Henderson BE, Yu MC, A cohort study of serum testosterone and hepatocellular carcinoma in Shanghai, China, Int J Cancer 63(4) (1995) 491-3. [PubMed: 7591255]

[8]. Yu MW, Yang YC, Yang SY, Cheng SW, Liaw YF, Lin SM, Chen CJ, Hormonal markers and hepatitis B virus-related hepatocellular carcinoma risk: a nested case-control study among men, J Natl Cancer Inst 93(21) (2001) 1644-51. [PubMed: 11698569]

[9]. Fwu CW, Chien YC, Kirk GD, Nelson KE, You SL, Kuo HS, Feinleib M, Chen CJ, Hepatitis B virus infection and hepatocellular carcinoma among parous Taiwanese women: nationwide cohort study, J Natl Cancer Inst 101(14) (2009) 1019-27. [PubMed: 19535774]

Cancer Epidemiol. Author manuscript; available in PMC 2020 February 10. 
[10]. Kanazir M, Boricic I, Delic D, Tepavcevic DK, Knezevic A, Jovanovic T, Pekmezovic T, Risk factors for hepatocellular carcinoma: a case-control study in Belgrade (Serbia), Tumori 96(6) (2010) 911-7. [PubMed: 21388051]

[11]. La Vecchia C, Negri E, Franceschi S, D’Avanzo B, Reproductive factors and the risk of hepatocellular carcinoma in women, Int J Cancer 52(3) (1992) 351-4. [PubMed: 1328066]

[12]. Plesko I, Preston-Martin S, Day NE, Tzonou A, Dimitrova E, Somogyi J, Parity and cancer risk in Slovakia, Int J Cancer 36(5) (1985) 529-33. [PubMed: 4055127]

[13]. Stanford JL, Thomas DB, Reproductive factors in the etiology of hepatocellular carcinoma. The WHO Collaborative Study of Neoplasia and Steroid Contraceptives, Cancer Causes Control 3(1) (1992) 37-42. [PubMed: 1311212]

[14]. Wu CH, Chan TF, Changchien CC, Yang CY, Parity, age at first birth, and risk of death from liver cancer: Evidence from a cohort in Taiwan, J Gastroenterol Hepatol 26(2) (2011) 334-9. [PubMed: 21261724]

[15]. Yu MW, Chang HC, Chang SC, Liaw YF, Lin SM, Liu CJ, Lee SD, Lin CL, Chen PJ, Lin SC, Chen CJ, Role of reproductive factors in hepatocellular carcinoma: Impact on hepatitis B- and Crelated risk, Hepatology 38(6) (2003) 1393-400. [PubMed: 14647050]

[16]. Maheshwari S, Sarraj A, Kramer J, El-Serag HB, Oral contraception and the risk of hepatocellular carcinoma, J Hepatol 47(4) (2007) 506-13. [PubMed: 17462781]

[17]. Fernandez E, Gallus S, Bosetti C, Franceschi S, Negri E, La Vecchia C, Hormone replacement therapy and cancer risk: a systematic analysis from a network of case-control studies, Int $\mathrm{J}$ Cancer 105(3) (2003) 408-12. [PubMed: 12704678]

[18]. McGlynn KA, Sahasrabuddhe VV, Campbell PT, Graubard BI, Chen J, Schwartz LM, Petrick JL, Alavanja MC, Andreotti G, Boggs DA, Buring JE, Chan AT, Freedman ND, Gapstur SM, Hollenbeck AR, Hou L, King LY, Koshiol J, Linet M, Palmer JR, Poynter JN, Purdue M, Robien K, Schairer C, Sesso HD, Sigurdson A, Wactawski-Wende J, Zeleniuch-Jacquotte A, Reproductive factors, exogenous hormone use and risk of hepatocellular carcinoma among US women: results from the Liver Cancer Pooling Project, Br J Cancer 112(7) (2015) 1266-72. [PubMed: 25742475]

[19]. Vekemans M, Robyn C, Influence of age on serum prolactin levels in women and men, Br Med J 4(5999) (1975) 738-9. [PubMed: 1212585]

[20]. Freeman ME, Kanyicska B, Lerant A, Nagy G, Prolactin: structure, function, and regulation of secretion, Physiol Rev 80(4) (2000) 1523-631. [PubMed: 11015620]

[21]. Yu-Lee LY, Prolactin modulation of immune and inflammatory responses, Recent Prog Horm Res 57 (2002) 435-55. [PubMed: 12017556]

[22]. Barone JA, Domperidone: a peripherally acting dopamine2-receptor antagonist, Ann Pharmacother 33(4) (1999) 429-40. [PubMed: 10332535]

[23]. Delitala G, Devilla L, Lotti G, Domperidone, an extracerebral inhibitor of dopamine receptors, stimulates thyrotropin and prolactin release in man, J Clin Endocrinol Metab 50(6) (1980) 1127 30. [PubMed: 7372791]

[24]. Hallstrom IP, Liao DZ, Assefaw-Redda Y, Ohlson LC, Sahlin L, Eneroth P, Eriksson LC, Gustafsson JA, Blanck A, Role of the pituitary in tumor promotion with ethinyl estradiol in rat liver, Hepatology 24(4) (1996) 849-54. [PubMed: 8855187]

[25]. Yamamoto R, Iishi H, Tatsuta M, Yamamoto T, Koike K, Kanda Y, Miyake A, Tsuji M, Terada N, Correlation between serum prolactin levels and hepatocellular tumorigenesis induced by 3'methyl-4-dimethylaminoazobenzene in mice, Br J Cancer 72(1) (1995) 17-21. [PubMed: 7599048]

[26]. Lawson DH, Sherman V, Hollowell J, The General Practice Research Database. Scientific and Ethical Advisory Group, Qjm 91(6) (1998) 445-52. [PubMed: 9709463]

[27]. Herrett E, Gallagher AM, Bhaskaran K, Forbes H, Mathur R, van Staa T, Smeeth L, Data Resource Profile: Clinical Practice Research Datalink (CPRD), Int J Epidemiol 44(3) (2015) 827-36. [PubMed: 26050254]

[28]. Jick H, Jick SS, Derby LE, Validation of information recorded on general practitioner based computerised data resource in the United Kingdom, Bmj 302(6779) (1991) 766-8. [PubMed: 2021768] 
[29]. Jick SS, Kaye JA, Vasilakis-Scaramozza C, Garcia Rodriguez LA, Ruigomez A, Meier CR, Schlienger RG, Black C, Jick H, Validity of the general practice research database, Pharmacotherapy 23(5) (2003) 686-9. [PubMed: 12741446]

[30]. Margulis AV, Fortuny J, Kaye JA, Calingaert B, Reynolds M, Plana E, McQuay LJ, Atsma WJ, Franks B, de Vogel S, Perez-Gutthann S, Arana A, Validation of Cancer Cases Using Primary Care, Cancer Registry, and Hospitalization Data in the UK, Epidemiology (2017).

[31]. Hartwell HJ, Petrosky KY, Fox JG, Horseman ND, Rogers AB, Prolactin prevents hepatocellular carcinoma by restricting innate immune activation of c-Myc in mice, Proc Natl Acad Sci U S A 111(31) (2014) 11455-60. [PubMed: 25049387]

[32]. Buckley AR, Putnam CW, Russell DH, Prolactin is a tumor promoter in rat liver, Life Sci 37(26) (1985) 2569-75. [PubMed: 2867449]

[33]. Brouwers JR, Assies J, Wiersinga WM, Huizing G, Tytgat GN, Plasma prolactin levels after acute and subchronic oral administration of domperidone and of metoclopramide: a cross-over study in healthy volunteers, Clin Endocrinol (Oxf) 12(5) (1980) 435-40. [PubMed: 7428183]

[34]. Fujino T, Kato H, Yamashita S, Aramaki S, Morioka H, Koresawa M, Miyauchi F, Toyoshima H, Torigoe T, Effects of domperidone on serum prolactin levels in human beings, Endocrinol Jpn 27(4) (1980) 521-5. [PubMed: 7460861]

[35]. Berinder K, Akre O, Granath F, Hulting AL, Cancer risk in hyperprolactinemia patients: a population-based cohort study, Eur J Endocrinol 165(2) (2011) 209-15. [PubMed: 21602317]

[36]. Levina VV, Nolen B, Su Y, Godwin AK, Fishman D, Liu J, Mor G, Maxwell LG, Herberman RB, Szczepanski MJ, Szajnik ME, Gorelik E, Lokshin AE, Biological significance of prolactin in gynecologic cancers, Cancer Res 69(12) (2009) 5226-33. [PubMed: 19491263]

[37]. Bhatavdekar JM, Patel DD, Chikhlikar PR, Shah NG, Vora HH, Ghosh N, Trivedi TI, Ectopic production of prolactin by colorectal adenocarcinoma, Dis Colon Rectum 44(1) (2001) 119-27. [PubMed: 11805572]

[38]. Bhatavdekar JM, Patel DD, Vora HH, Shah NG, Chikhlikar PR, Ghosh N, Prolactin as a local growth promoter in patients with locally advanced tongue cancer: GCRI experience, Head Neck 22(3) (2000) 257-64. [PubMed: 10748449]

[39]. Hatfill SJ, Kirby R, Hanley M, Rybicki E, Bohm L, Hyperprolactinemia in acute myeloid leukemia and indication of ectopic expression of human prolactin in blast cells of a patient of subtype M4, Leuk Res 14(1) (1990) 57-62. [PubMed: 1968111]

[40]. Gado K, Rimanoczi E, Hasitz A, Gigler G, Toth BE, Nagy GM, Paloczi K, Domjan G, Elevated levels of serum prolactin in patients with advanced multiple myeloma, Neuroimmunomodulation 9(4) (2001) 231-6. [PubMed: 11847486]

[41]. Yeh YT, Lee KT, Tsai CJ, Chen YJ, Wang SN, Prolactin promotes hepatocellular carcinoma through Janus kinase 2, World J Surg 36(5) (2012) 1128-35. [PubMed: 22392353]

[42]. Scheuer A, Grun R, Lehmann FG, Peptide hormones in liver cirrhosis and hepatocellular carcinoma, Oncodev Biol Med 2(1-2) (1981) 1-10. [PubMed: 6272236]

[43]. Costantini S, Capone F, Maio P, Guerriero E, Colonna G, Izzo F, Castello G, Cancer biomarker profiling in patients with chronic hepatitis $\mathrm{C}$ virus, liver cirrhosis and hepatocellular carcinoma, Oncol Rep 29(6) (2013) 2163-8. [PubMed: 23564159]

[44]. Kong X, Wu W, Yuan Y, Pandey V, Wu Z, Lu X, Zhang W, Chen Y, Wu M, Zhang M, Li G, Tan S, Qian P, Perry JK, Lobie PE, Zhu T, Human growth hormone and human prolactin function as autocrine/paracrine promoters of progression of hepatocellular carcinoma, Oncotarget 7(20) (2016) 29465-79.

[45]. Simon-Holtorf J, Monig H, Klomp HJ, Reinecke-Luthge A, Folsch UR, Kloehn S, Expression and distribution of prolactin receptor in normal, fibrotic, and cirrhotic human liver, Exp Clin Endocrinol Diabetes 114(10) (2006) 584-9. [PubMed: 17177141]

[46]. Kloehn S, Otte C, Korsanke M, Arendt T, Clemens A, Glasow A, Bornstein SR, Folsch UR, Monig H, Expression and distribution of the prolactin receptor in normal rat liver and in experimental liver cirrhosis, Horm Metab Res 33(7) (2001) 394-401. [PubMed: 11507675]

[47]. Reddymasu SC, Soykan I, McCallum RW, Domperidone: review of pharmacology and clinical applications in gastroenterology, Am J Gastroenterol 102(9) (2007) 2036-45. [PubMed: 17488253] 
[48]. Forbes N, Cooray M, Al-Dabbagh R, Yuan Y, Tse F, Liu LW, Xenodemetropoulos T, Domperidone Prescribing Practices Exposed Patients to Cardiac Risk despite a "Black Box" Warning: A Canadian Tertiary Care Center Study, Can J Gastroenterol Hepatol 2016 (2016) 2937678.

[49]. Osadchy A, Moretti ME, Koren G, Effect of domperidone on insufficient lactation in puerperal women: a systematic review and meta-analysis of randomized controlled trials, Obstet Gynecol Int 2012 (2012) 642893.

[50]. Anderson GD, Gender differences in pharmacological response, Int Rev Neurobiol 83 (2008) 110. [PubMed: 18929073]

[51]. Tran C, Knowles SR, Liu BA, Shear NH, Gender differences in adverse drug reactions, J Clin Pharmacol 38(11) (1998) 1003-9. [PubMed: 9824780]

[52]. Simard C, Michaud V, Gibbs B, Masse R, Lessard E, Turgeon J, Identification of the cytochrome P450 enzymes involved in the metabolism of domperidone, Xenobiotica 34(11-12) (2004) 101323. [PubMed: 15801545]

[53]. Ward BA, Morocho A, Kandil A, Galinsky RE, Flockhart DA, Desta Z, Characterization of human cytochrome $\mathrm{P} 450$ enzymes catalyzing domperidone N-dealkylation and hydroxylation in vitro, Br J Clin Pharmacol 58(3) (2004) 277-87. [PubMed: 15327587]

[54]. Wolbold R, Klein K, Burk O, Nussler AK, Neuhaus P, Eichelbaum M, Schwab M, Zanger UM, Sex is a major determinant of CYP3A4 expression in human liver, Hepatology 38(4) (2003) 97888. [PubMed: 14512885] 
Table 1.

Characteristics of liver cancer cases and matched controls by sex in the Clinical Practice Research Datalink, 1987-2016

\begin{tabular}{|c|c|c|c|c|}
\hline & \multicolumn{2}{|c|}{ Men, No. (\%) } & \multicolumn{2}{|c|}{ Women, No. (\%) } \\
\hline & Cases $n=1366$ & Controls $n=5461$ & Cases $n=555$ & Controls $n=\mathbf{2 2 2 0}$ \\
\hline \multicolumn{5}{|l|}{ Diagnosis year } \\
\hline$\leq 1999$ & $70(5.1)$ & & $56(10.1)$ & \\
\hline $2000-2004$ & $159(11.6)$ & & $58(10.5)$ & \\
\hline $2005-2009$ & $394(28.8)$ & & $174(31.4)$ & \\
\hline$\geq 2010$ & $743(54.4)$ & & $267(48.1)$ & \\
\hline \multicolumn{5}{|l|}{ Age at diagnosis } \\
\hline$\leq 54$ & $152(11.1)$ & & $57(10.3)$ & \\
\hline $55-59$ & $121(8.9)$ & & $34(6.1)$ & \\
\hline $60-64$ & $160(11.7)$ & & $49(8.8)$ & \\
\hline $65-69$ & $213(15.6)$ & & $71(12.8)$ & \\
\hline $70-74$ & $233(17.1)$ & & $98(17.7)$ & \\
\hline $75-79$ & $223(16.3)$ & & $84(15.1)$ & \\
\hline $80-84$ & $172(12.6)$ & & $91(16.4)$ & \\
\hline$\geq 85$ & $92(6.7)$ & & $71(12.8)$ & \\
\hline \multicolumn{5}{|c|}{ Body mass index $\left(\mathrm{kg} / \mathrm{m}^{2}\right)$} \\
\hline$<25.0$ & $433(31.7)$ & $1797(32.9)$ & $251(45.2)$ & $888(40.0)$ \\
\hline $25.0-<30.0$ & $518(37.9)$ & $2379(43.6)$ & $162(29.2)$ & $777(35.0)$ \\
\hline$\geq 30$ & $415(30.4)$ & $1285(23.5)$ & $142(25.6)$ & $555(25.0)$ \\
\hline \multicolumn{5}{|l|}{ Smoking status } \\
\hline Current & $387(28.3)$ & $1084(19.8)$ & $144(25.9)$ & $341(15.4)$ \\
\hline Former & $854(62.5)$ & $3386(62.0)$ & $312(56.2)$ & $1310(59.0)$ \\
\hline Never & $125(9.2)$ & $991(18.1)$ & $99(17.8)$ & $569(25.6)$ \\
\hline \multicolumn{5}{|c|}{ Chronic HBV/HCV infection } \\
\hline Yes & $87(6.4)$ & $13(0.2)$ & $15(2.7)$ & $4(0.2)$ \\
\hline No & 1,279 (93.6) & $5,448(99.8)$ & $540(97.3)$ & $2,216(99.8)$ \\
\hline \multicolumn{5}{|l|}{ Diabetes } \\
\hline Yes & $547(40.0)$ & $782(14.3)$ & $110(19.8)$ & $228(10.3)$ \\
\hline No & $819(60.0)$ & $4679(85.7)$ & 445 (80.2) & $1992(89.7)$ \\
\hline \multicolumn{5}{|c|}{ Alcohol-related disorders } \\
\hline Yes & $317(23.2)$ & $319(5.8)$ & $35(6.3)$ & $37(1.7)$ \\
\hline No & $1,049(76.8)$ & $5,142(94.2)$ & $520(93.7)$ & $2,183(98.3)$ \\
\hline \multicolumn{5}{|c|}{ Rare genetic disorders } \\
\hline Yes & $50(3.7)$ & $6(0.1)$ & $7(1.3)$ & $4(0.2)$ \\
\hline No & $1,316(96.3)$ & $5455(99.9)$ & $548(98.7)$ & $2,216(99.8)$ \\
\hline \multicolumn{5}{|l|}{ Statin use } \\
\hline Yes & $541(39.6)$ & $2093(38.3)$ & $160(28.8)$ & $667(30.0)$ \\
\hline
\end{tabular}




\begin{tabular}{|c|c|c|c|c|}
\hline & \multicolumn{2}{|c|}{ Men, No. (\%) } & \multicolumn{2}{|c|}{ Women, No. (\%) } \\
\hline & Cases n=1366 & Controls n=5461 & Cases $n=555$ & Controls n=2220 \\
\hline No & 825 (60.4) & 3368 (61.7) & 395 (71.2) & $1553(70.0)$ \\
\hline
\end{tabular}

HBV=hepatitis B virus; HCV=hepatitis C virus; Rare genetic disorders include hemochromatosis, alpha-1 antitrypsin deficiency, Wilson disease, tyrosinemia, porphyria 


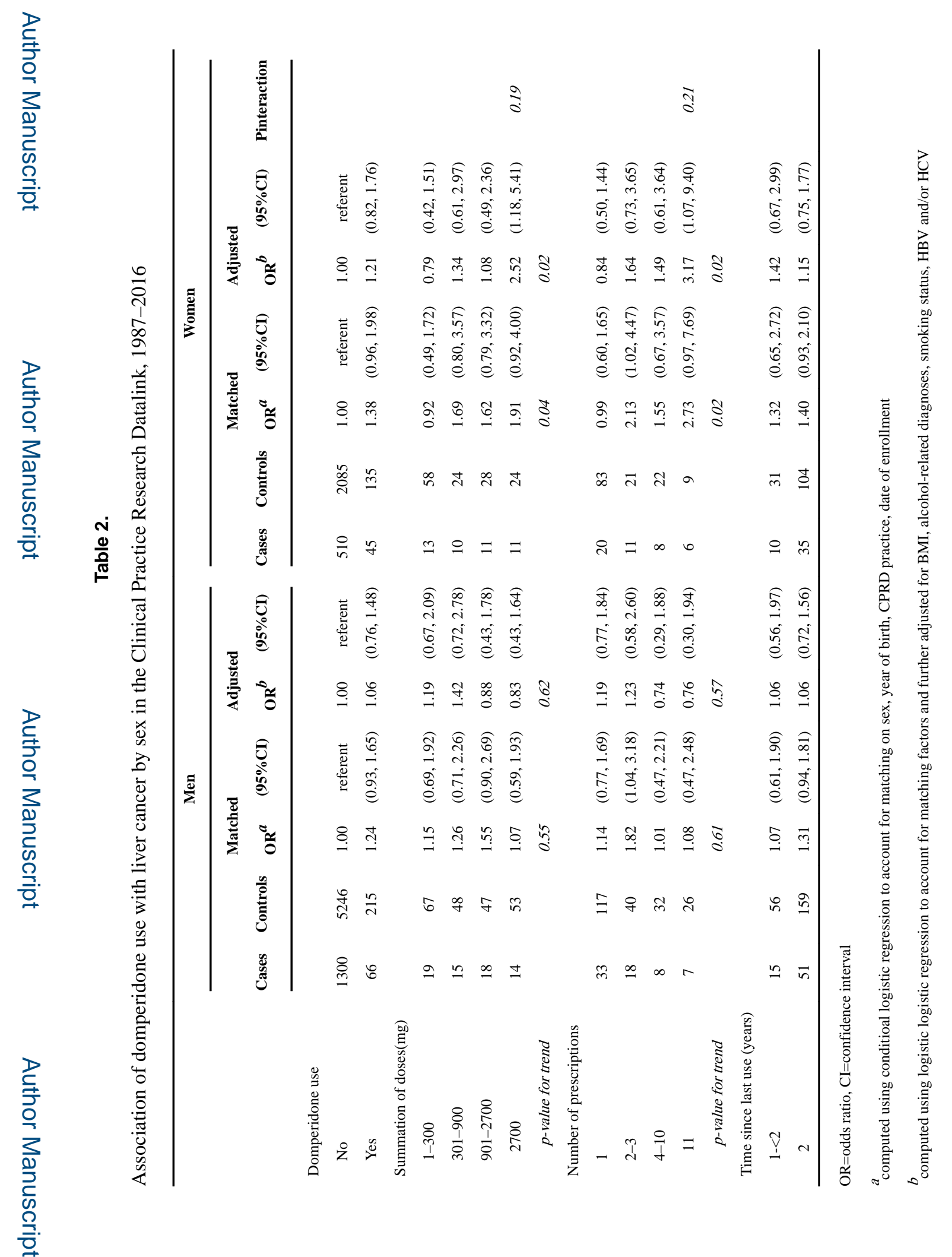

Cancer Epidemiol. Author manuscript; available in PMC 2020 February 10. 